\title{
Profiling adult literacy facilitators in development contexts: An ethnographic study in Ethiopia
}

\author{
Turuwark Zalalam Warkineh ${ }^{1}$. \\ Alan Rogers ${ }^{2}$ - Tolera Negassa Danki ${ }^{3}$
}

(C) The Author(s) 2017. This article is an open access publication

\begin{abstract}
Teachers/facilitators in adult literacy learning programmes are recognised as being vital to successful learning outcomes. But little is known about them as a group. This small-scale research project comprising ethnographic-style case studies of five adult literacy facilitators (ALFs) in Ethiopia seeks to throw some light on these teachers, their backgrounds and what they bring to their teaching, with a view to improving the effectiveness of their work. The researchers found that all of the ALFs had high levels of commitment, but none of the ALFs received much in the way of training, and professional support for their role was in some cases missing. The degree (and their perception) of their own literacy practices varied greatly among them, even in their common use of mobile phones. It also emerged that while they had all fought very hard for their own education, one of the main reasons all of them stated for going into literacy teaching was not a general belief in the value of education but their priority need of a regular income. Another insight is that the female ALFs struggled more than their male counterparts in engaging learners; the women were criticised more excessively than the men. This research reveals something of the diversity of facilitators, and concludes that further such studies are needed in different contexts.
\end{abstract}

\footnotetext{
Alan Rogers

rogalaprof@gmail.com

Turuwark Zalalam Warkineh

tiruworkzelalem@gmail.com

Tolera Negassa Danki

toleranegassad@gmail.com
}

1 Adult Education and Community Development Department, Education and Behavioral Sciences College, Bahir Dar University, Bahir Dar, Ethiopia

2 University of East Anglia, Norwich, UK

3 College of Education and Behavioral Science, Arsi University, Arsi, Oromia, Ethiopia 
Keywords adult literacy teaching $\cdot$ adult educators $\cdot$ facilitators $\cdot$ Integrated Functional Adult Literacy (IFAL) programme $\cdot$ mobile phone literacy

Résumé Établir le profil du personnel d'alphabétisation pour adultes dans les contextes de développement : étude ethnographique en Éthiopie - Les enseignants et animateurs actifs dans les programmes d'alphabétisation pour adultes sont réputés essentiels pour obtenir des résultats d'apprentissage concluants. Ils sont cependant assez méconnus en tant que groupe. Le présent projet de recherche à petite échelle implique des études de cas de style ethnographique sur cinq animateurs en alphabétisation des adultes en Éthiopie. Il poursuit le but de faire quelque peu connaitre ces enseignants ainsi que leurs parcours et ce que ces derniers apportent à leur enseignement, dans l'objectif d'améliorer l'efficacité de leur travail. Les chercheurs ont constaté que ces animateurs ont tous un niveau élevé d'engagement, mais qu'aucun ne bénéficie véritablement d'une formation, et qu'un soutien professionnel pour leur action est absent dans certains cas. Le niveau (et leur propre perception) de leurs pratiques lettrées varie grandement entre eux, jusque dans leur utilisation courante du téléphone portable. Il est en outre apparu que s'ils ont tous lutté âprement pour leur propre instruction, l'une des principales raisons énoncées par chacun d'entre eux pour leur activité est non pas la conviction de la valeur générale de l'instruction, mais leur besoin prioritaire d'un revenu régulier. Un autre élément dévoile que les animatrices s'efforcent davantage que leurs collègues masculins de motiver les apprenants; et que les femmes sont davantage critiquées que les hommes. Ce projet fournit quelques informations sur la diversité du personnel d'alphabétisation, et conclut que d'autres études de ce type seraient nécessaires dans différents contextes.

\section{Researching adult literacy facilitators}

Adult literacy is an important factor in development (Hanemann 2015), both as a contributing factor to economic growth and (in the form of "literacy rates") as a development indicator (UNESCO 2006; UNDP 2015). It is therefore important that adult literacy learning programmes (ALLPs) should be as effective as possible. It is widely regarded that the effectiveness of ALLPs depends to a very large degree on the teachers (Torres 2004, 2009; UIL 2009). However, although the literature relating to ALLPs is extensive, studies considering the literacy teachers, facilitators or tutors are relatively few. There are some studies concerned with the training (or lack of training) of facilitators (e.g. Openjuru 2002; Youngman and Singh 2005; McCaffery 2004; Diarra 2011; UIL 2012; Doyle et al. 2016); with the competences they need to be effective (e.g. Lytle et al. 1993; Oluoch et al. 2014; Wahlgren 2016); with their sense of identity in their task (e.g. Paluch 2013) or with their educational qualifications (e.g. Maruatona 2012). There are also studies of facilitators contained in evaluations of individual literacy programmes (e.g. Robinson-Pant 2001; Bartlett 2010). But, as Frank Youngman and Madhu Singh point out in their 2005 report, 
Information is needed on the different types of adult educators, their identity and profiles, their numbers, their working conditions, their training needs ... and other basic data (Youngman and Singh 2005, p. 9).

The Education for All Global Monitoring Report on literacy (UNESCO 2006) revealed the wide range of people who teach literacy to adults in developing countries. These include full-time teachers in formal schools who teach adults outside their main working hours, other full-time employees of government departments or non-governmental organisations (NGOs), such as community development assistants and health and agricultural extension ${ }^{1}$ workers who are required to teach literacy to adults as part of their professional duties, and in some countries qualified contract staff who teach adult basic education (ABE) full- or part-time in schools, colleges and community learning centres (Mayombe and Lombard 2016). However, the above three groups are relatively small. The large majority are

local people with no formal [teaching] qualifications, engaged part-time and on a casual basis ... [with] no previous experience of teaching. ... People in this category may have limited formal education, though some are well educated (UNESCO 2006, p. 225).

These are often referred to as "volunteers" in the sense of not being professionals employed on long-term contracts; most are paid, although usually a pittance and often irregularly.

Little is known about these people, neither in quantitative nor qualitative terms. A lot of assumptions are made covering many different contexts. Rose-Marie Weber provides one of the best summaries of what is currently known about adult literacy teachers:

Few teachers of adult [literacy], even where adult education has become professionalized, have a background in both adult education and literacy. In some settings, it is thought that anyone who is literate can teach literacy, so that secondary students may teach the contents of a primer as a requirement of graduation or inmates in correctional settings may pair up with low literates to demonstrate basic skills. Many teachers of adults ... may receive a few hours of training to heighten their awareness of what can be taught and how. Teachers with experience in teaching children may be enlisted to provide instruction for adult literacy but with little recognition given to differences between children and adult learners (Weber 1999, p. 177).

\section{Using ethnographic approaches}

Part of the problem in conducting research on adult literacy facilitators (ALFs) is the "major, regular turnover of facilitators" (UNESCO 2006, p. 227). Many teach for only one year, so capturing quantitative data on a long-term basis is impossible. But the increasing use of ethnographic approaches in the study of literacy suggests that this

\footnotetext{
1 Agricultural and health extension workers are full-time government employees who relate directly with farming and (mainly) women's groups promoting good farming and health practices.
} 
approach could yield fruit when studying ALFs (Ellen 1984; Barton 2012). There have been many ethnographic-style studies of everyday literacy practices since the pioneering Social Uses of Literacy (Prinsloo and Breier 1997); these are based on what are called the New Literacy Studies [NLS], which see literacy as a set of social practices rather than as a neutral personal skill, and explore the different ways literacy is practised in the community or workplace (e.g. Street 1993; Robinson-Pant 2004; Nabi et al. 2009; Ghose 2007; Gebre et al. 2009; Openjuru et al. 2016). But on the whole, literacy facilitators have not been studied in the same way. Marta Paluch notes:

It is generally agreed that the work of adult literacy facilitators is central to the learning experience of participants in literacy classes ... yet there is little research on their practices. While proponents of NLS have carried out ethnographic studies of [the literacy practices of] people learning to read, there has been little focus on the practices of ALFs (Paluch 2013, p. 5).

\section{The research project}

This study grew out of an initial survey of adult literacy teachers in the Integrated Functional Adult Education (IFAE) programme in one area of Ethiopia This twoyear government-run national programme, meant for adults aged 15 years and beyond, commenced in 2013. The programme "seeks to link writing, reading and numeracy skills to livelihoods and skills training in areas such as agriculture, health, civic, cultural education, etc." (MoE 2010, p. 37). The initial survey was conducted by Bahir Dar University's Department of Adult Education and Community Development in 2015. It pointed out that

The Ministry ... guidelines ... said that "the majority of facilitators of this programme should come from development field personnel trained for the different packages ... This includes agricultural and health extension workers and school teachers. In addition to these experts, ABE [alternative basic education] facilitators and other facilitators in the community can serve as facilitator." But to the contrary, we found out that the majority of the facilitators of the IFAL [Integrated Functional Adult Literacy] programme are 10th grade completers ... only a very few primary school teachers, ... as well as health and agricultural extension workers are serving as facilitators (Zalalam et al. 2015).

Of the 162 facilitators surveyed in depth, nearly 90 per cent (145) were "people from the community"; only 17 were extension workers and schoolteachers. The total numbers involved are large. The Amhara National Regional State Education Bureau's annual report stated that

there are 14,381 adult literacy facilitators who were employed on contract bases (they are not permanent employees and are paid a small sum every month). This number does not include extension workers who [facilitate literacy] part-time. ${ }^{2}$

\footnotetext{
${ }^{2}$ This information was obtained from Mr. Tekalign, Deputy Head of the Non-Formal Education and Community Development Unit at Oromia Region (personal communication 5 October 2016).
} 
In another regional state, Oromia, the number of facilitators employed on a temporary contract is $10,967 .{ }^{3}$ Since there are nine regional states and two municipal administrations in Ethiopia, we calculate that there must be between 100,000 and 120,000 community-based adult literacy facilitators in Ethiopia, excluding full-time employed extension workers and schoolteachers. This is a large and potentially influential group of local community development workers.

On the basis of the survey carried out by Bahir Dar University's Department of Adult Education and Community Development in 2015, we agreed to look in greater depth at some of these community ALFs to see if we could flesh out details of their background. We used an ethnographic case-study approach (Hammersley 1992); as David Barton says, a good example of an ethnographic case study can challenge dominant literacy discourses (Barton 2013, p. 214). Thus, we studied a small number of individual ALFs from the Integrated Functional Adult Literacy (IFAL) Programme in two districts of Ethiopia to obtain information about their backgrounds and how they work. The research we present here is intended as a pilot study to see what lessons may be learned.

Our research team consisted of Turuwark Zalalam of Bahir Dar University, who led the first survey, and Tolera Negassa of Arsi University, who joined in for the fieldwork so as to obtain information from a different context. Six ALFs were chosen for what ethnographers call "thick descriptions" (Geertz 1973) or detailed accounts to form ethnographic-style case studies. They were selected with the help of the local literacy programme co-ordinators, three in each region. We sought a gender balance, but it was not possible to complete one of the case studies with a female ALF. The process was intensive: over several days, each facilitator was visited three or four times for observation and in-depth interviews in their class, their workplaces and homes. Interviews were conducted in Amharic and Afan Oromo, the local languages, and were transcribed and translated into English to ensure that as far as possible their authentic voices were heard. Detailed notes of the discussions and observations were made and analysed, and photographs were taken. Research ethics protocols were observed, informed consent obtained, and sometimes difficult gender relations were negotiated. Alan Rogers, who acted as research supervisor, discussed and monitored the process and findings as the case studies were developed.

Initially, our research focused on what literacy practices these ALFs engaged in; since the facilitators were seeking to induct non-literate adults into literacy practices, it was important to know whether they themselves engaged in such practices. A preliminary study of two facilitators was completed (Negassa et al. 2017), but this revealed that a fuller exploration of the background of these facilitators was needed - their prior experience and what they brought to their teaching of literacy. Hence, we extended the study to cover more ALFs. Our research questions were

Where did they come from?

What experiences did they bring?

\footnotetext{
3 This information was obtained from Mr. Marew Derso, Head of IFAL Coordination Office at Amhara National Regional State (personal communication 4 October 2016).
} 
What are their main concerns while teaching? and

What are their aspirations (including future plans for adult literacy teaching)?

We begin with a brief profile of the five ALFs whom we interviewed, then focus on a number of issues which arose from our findings, highlighting similarities and differences between them.

\section{Brief profiles of the five ALFs}

Selam, in her late twenties, comes from a rural background. Her father is a priest in the Coptic Church. She is married with one child. Her main occupation is cooking and selling injera (a type of bread, and an Ethiopian staple) for her livelihood. She struggled hard, at times against the wishes of her family, to attend school and reached Grade 10 (the last year of formal schooling) ${ }^{4}$ but was unable to proceed to further or higher education. After working in a variety of occupations and getting married, she was invited to teach on the IFAL programme.

Konjit, in her thirties, comes from a farming background. She is single, having been divorced from an early forced marriage. Through personal determination she completed schooling and is a university graduate, but has been unable to find a professional position, unlike her brothers and sisters who are government employees. Instead, she runs her own coffee and souvenir stall besides teaching literacy to adults.

Yared is a young man in his twenties. His father is a priest in the Coptic Church and Yared was sent to church education to follow in his footsteps, but switched to a government school instead. He completed Grade 10, but was unable to join the preuniversity course. He studied part-time at a teacher training college to qualify as a school-teacher. He is now studying part-time for a business management diploma. He shows great entrepreneurial spirit and has a number of business interests. He balances his work as an ALF with his studies and his enterprises.

The other two ALFs are students in their early twenties. Bikila, from a farming background, completed Grade 10 before moving to the city to find work and pursue his studies. He is attending a teacher education summer programme with a view to pursuing a career as a schoolteacher. Guta, also from a farming background, completed Grade 10 and the two-year pre-university course, but did not take up his place at university. He too is studying teacher education in the summer programme, and is also engaged in part-time study of accounting at diploma level for a career in business, parallel to teaching literacy to adults.

\footnotetext{
${ }^{4}$ Children in Ethiopia enter primary school, which has two cycles (Grades 1-4 and 5-8), at age 7. They progress to secondary school (Grades 9-10) and sit for their school leaving exam at the end of Grade 10. If they get a pass mark (pass marks vary from year to year), they will either join a pre-university programme (Grades 11-12) or pursue their diploma studies in various fields of study. Those who do not qualify for the pre-university class but have the required mark for skills training can join technical and vocational education and training (TVET) programmes. Those who qualify for neither the preparatory course nor TVET may sit for the national examination again and improve their result.
} 


\section{Some comparisons and contrasts}

These five ALFs make an interesting group with some commonalities and some differences. The focus of the discussion here is what they brought to their literacy teaching.

\section{Background and family}

While all of them came from rural backgrounds, moving into urban or semi-urban environments in search of income or training, their family backgrounds were different. Selam's father was a priest in the Orthodox (Coptic) church and a teacher of Amharic; Yared's father was also a priest - indeed, Yared had himself begun training for the priesthood. The parents of the others were farmers with ambitions for their children either to get married or find employment to support their families.

\section{Schooling}

What was most striking about these ALFs was their deep commitment to schooling; every one of them had struggled to acquire their education. All came under pressure from their families, some in favour of schooling with the intention of preparing them for well-remunerated jobs, others opposed to schooling.

Selam said that when she reached Grade 10, she took the entry examination for the pre-university course but did not qualify for that course. She tried to pursue a diploma on her own, but could not afford the fees. She said her family were disappointed with her because they were hoping that she would get a degree and support them during their old age.

Konjit had an even harder passage but got further. She started school but was forced by her parents to leave to get married. Out of what she called her "strong determination to learn", she escaped to a neighbouring town but had to return because she "could not find anyone to support" her. Her school principal found her crying on the roadside and persuaded her parents to allow her to attend school. Her husband treated her

"brutally. He used to wait for me by the roadside and he would take my exercise books and tear them up in front of me ... he used to beat me ... threaten me ... Until I reached Grade 4, I lived a life of hell ..."

When she reached Grade 5, her husband asked for a divorce. Her parents, dissatisfied with the divorce, gave her a lot of domestic work, hoping that she would give up her schooling and be reconciled with her husband. But her determination increased. She dreamed of becoming a gender equality advocate because

"many rural women are oppressed ... I had faced a bitter challenge ... I do not want my sisters to be denied their rights to live the life they deserve ... their right to learn ... their right to choose their soulmates ..." 
She passed the national examinations for university entry, and chose gender studies for her courses, but was assigned to English Language and Ethiopian Literature. She said that, though she tried hard to switch department, she couldn't. Since she had no choice, she pursued her undergraduate studies and graduated with a Bachelor's degree. She said that her university studies were "challenging" because she had difficulty with the English language, problems with money and other difficulties; as a result, "I scored the lowest grade point average."

Yared's experience was different but also difficult. His eldest sister was forced to marry when very young, and his second sister left home to stay with a relative in order to attend school; Yared said that if she had stayed at home, she too would have been forced to marry. Yared's older brother was forced into church education to become a priest like his father, but he left after three years and started formal schooling. He graduated from university with a Bachelor's degree in Management and now works for the government. Yared's younger sister was "lucky" to go to school (Yared commented that "owing to a strong push from the government, many rural people have learned the consequences of early marriage"), but she could not continue after Grade 6; she is now married as arranged by her family. His youngest brother attends school, and is now in Grade 5. Yared, like his older brother, was sent by his father to train to become a deacon. He attended church education for three years and was able to read the Bible and other religious books. But, he said,

"these learners are supposed to beg for their food by wandering from home to home. One day, a vicious dog ripped my clothes and terrified me so much that I have hated church education since then."

So, while attending church education, he also went to formal school without telling his parents. He asked his teachers to allow him to attend only on holidays to be able to hide from his father. His teachers were supportive, so his parents did not know that he was attending school. When he reached Grade 5, his teachers persuaded his parents to let him continue full-time in the formal school. When he completed Grade 10, he worked for a time and "then, with the money I saved, I went to a teacher training college and spent a year training and got the certificate in teaching." But his interests have changed, and he is now studying part-time to obtain his diploma in management studies.

Bikila had something of an easier course; his family sent him and his brothers to school. His older brother is now employed in government service. Bikila completed Grade 10, but did not qualify for the preparatory class to higher studies.

\footnotetext{
"As a result, ... I went back to traditional farming like my parents ..., but ... some of my family members and the local community were not happy because they expected me to continue on the educational ladder after Grade 10 and to graduate from college and earn money from government office employment. Because of the push from my family and community, I decided to ... move to look for a job in a town somewhere."
}

He is now studying part-time to obtain his teaching certificate. 
Guta's parents valued schooling. They had attended adult literacy classes under the Dergue regime, ${ }^{5}$ and as a result, both his mother and his father act as voluntary secretaries to local credit and savings groups. Guta is the fifth of eight children; his brothers are professionally employed. Guta attended school to Grade 10 and for financial reasons joined a skills-oriented training programme instead of the preparatory course for university. He said that his mother was a particular support to her children in reading and writing, supervising their school homework and providing educational materials.

"I am very much influenced by my mother's qualities, character and determination. My mother is very active, and keen to advance our family. She works very hard to cover all our livelihood expenses."

He is now studying accountancy part-time and takes other courses as they become available: "I started computer classes at a private school, but I could not afford the fee and dropped out."

\section{Poverty}

What drove them in their work as ALFs, however, was not primarily altruism or high ideals about education. Everyone said that they sought this work in the expectation that it would yield an income which, although small, would at least be regular. All were driven by poverty - either their own or that of their families. All were expected to support their parents and other family members. Their careers after schooling consisted of efforts to earn a living.

Selam worked as a labourer on a building site and married a construction worker. When her child was born, she worked for a time as a janitor but then started her own small business, cooking and selling injera and helping her mother-in-law to brew and sell tella, an Ethiopian beer typically made from teff and sorghum grains. This is her main occupation now. She said that she sought work as a literacy teacher to supplement this income.

Konjit, despite her degree, was unable to obtain professional employment. For a time, she traded in guava but then started a roadside stall, brewing coffee and selling souvenirs to visitors to a local monastery. Again, she sought adult teaching as a means of supplementing her income.

Yared said that, after completing his schooling,

"I did not want to be a burden to my parents. I started manual work at a nearby flower farm. The farm required a Grade 10 certificate. I was assigned to work in the mechanics' section but I had no experience of such work ... Not to lose the job, I was keen to learn from experts by closely observing them. Sometimes I did not go for tea break or lunch in order to practise while the machines were free ... After a few months, I was able to work everything by

\footnotetext{
5 The Dergue regime (the military junta which ruled Ethiopia from 1974 to 1991) initiated an intensive National Literacy Campaign (NLC), which ran from 1979-1990/91. For more details on the goals, approaches and results of the NLC, see Werqneh 2012.
} 
myself. I also received some training in mechanics [in a short-term training course organised and provided by the farm]."

Then he offered his services to a local political party as an unpaid worker with a view to gaining employment as a teacher. They gave him a small office and from there he built up his thriving business interests. He first started a small library and then a typing and copying business which has grown to employ other people. His interests have expanded into various business interests which, he says, yield him a "more-than-adequate income", so that his work as an ALF is not now primarily for money, as explained below.

Both Bikila and Guta say that they are teaching adults to earn an income while studying. Bikila reported that, during his stay in the city, he was employed as a day labourer in the construction industry "to earn a living and support [his] poor family dependent on subsistence farming". He felt that the income from this daily labour was better but, as the job in the construction industry is seasonal, he could not always find work. So, he turned to IFAL for employment as facilitator. Guta too worked as a labourer, but decided to change to a job that (as he said) seemed "a little bit more permanent and free of daily labour". Thus, he dropped out of subsistence farming and construction, and instead joined IFAL, teaching adults. He said he assumed that there would be more opportunity in education.

All of them were driven by poverty, real or perceived. But beyond this, Konjit, Yared (initially) and Guta joined IFAL as a step towards a career in teaching; they believed it would lead to a more substantial job.

\section{Recruitment}

Bikila and Guta both became ALFs through a competitive examination - that was the entry system for the woreda (district) they worked in. However, the recruitment process is different in other woredas. Konjit said that she worked as a volunteer with the ruling political party in her kebele (sub-district), recruiting members, leading "cell meetings" and writing up the minutes of meetings. After six months, she was nominated as an adult literacy facilitator. "This is how I started teaching adults." Selam likewise began working voluntarily at the kebele office, "hoping they would give me a job one day". Her work involved mobilising people for meetings and elections. She was also asked to oversee government-supported social and health groups, reporting on attendance and activities of these groups. As a result of this unpaid work, she was appointed adult literacy facilitator.

Yared's experience was similar:

"As soon as I graduated, I came back to my home village to look for a job while I continued working as a volunteer in the kebele ... Then, since I was a ruling party member and an active participant, one of the kebele leaders asked me if I wanted to teach adults and children. I said no. I didn't want to teach adults for 500 birr which won't even buy a shoe ... However, they told me that I would be given an educational opportunity later. Since I was eager to continue with my diploma, I accepted the proposal ... But they lied to me; it 
was a false promise. It has been nearly three years now since I started, but I got no educational opportunity."

\section{Payment}

Since all these ALFs were primarily motivated by the need for income to support them, it is ironic that the payment is so small. Selam, Konjit and Yared earn 500 birr a month (half of what a construction worker earns), Bikila and Guta earn 630 birr a month. ${ }^{6}$ Without exception, they complain that this is not enough. Selam said that "the salary can't cover my home expenses", and Konjit said that it was not enough to cover her living costs, hence her roadside stall. Yared commented,

"The payment is nothing compared to the money I get from my business. Many of the facilitators complain about the payment ... It is difficult to get facilitators. The 10th grade completers prefer to work in nearby factories as workers and guards than as facilitators. This is because they earn a minimum of 1,000 birr per month, which is almost double what I get as a facilitator ... there was one female facilitator hired to support me. She had a diploma but she didn't stay long; she left when she got a better job. In place of her, another male facilitator who had a diploma was hired; he left soon after."

Guta and Bikila manage on their 630 birr by sharing accommodation with fellow students. Guta said, I "rent the room for 300 birr and share it with my colleague (150 birr each). I pay school fees of 360 birr, and the remaining 120 serves to buy food. I am sometimes supported by my brother who works at one of the private banks". Bikila says he spends half of what he earns on his room rent, 300 birr a month: “... the current salary payment is not enough. ... for rent, food, clothes, supporting parents and health insurance."

All of the five ALFs thus supplement their facilitation income. Konjit told how her voluntary work at the kebele yielded another opportunity: "Since I was an active participant in the kebele, I got the chance to be supported by an NGO ... which lent me 5,000 birr as seed money to be repaid every month for two years." Since the NGO did not give her any kind of business training, she said that she first opened a bank account for the money. Afterwards "I decided to make and sell coffee around the monastery tourist site where I was brought up, because it doesn't require sophisticated skills and materials." From the profits from her roadside stall, she was able to repay the debt ahead of time. Yared said that "from my business work, I earned more than 30,000 birr in less than two weeks."

The insufficiency of the salary as an ALF meant, for each of the facilitators, balancing priorities. Selam said her injera cooking and selling came first but she still found time for her classes; Konjit closed her stall on teaching days. Yared agreed with his students which days he would teach and which he should attend his courses,

\footnotetext{
${ }^{6}$ The difference is due to the decentralisation of the national IFAL programme, which allows different districts to pay different rates; it is not a gender issue, as Yared is also paid 500 birr a month, despite teaching two classes. 500 birr has an exchange value of approx. 21 US dollars.
} 
and Bikila and Guta found themselves balancing the time they spent studying and the time spent on their literacy classes.

\section{Teaching}

As facilitators, they are expected to mobilise their own learners and to teach three days a week for two hours a day in two groups; a first and a second level. Both Bikila and Guta commented on the large sizes of their classes: Guta had 46 learners in his first year, and 26 in his second; Bikila had 60 in year 1 (15 men and 45 women) and 36 in year 2 (9 men and 27 women), but not all attended every evening. The two women had virtually no classes at all - their enrolled learners often did not turn up. Selam explained that many of them despised her, saying,

"'You are nagging us for your own benefit ... so as not to lose your job. Why don't you first teach your mother-in-law? She is also mehayim [illiterate]. You reached Grade 10 but you are doing what we are doing, baking injera ... selling tella ... nothing new. So why do you bother us day after day?'”

Konjit had much the same experience:

"They say, 'You were educated, but you reached nowhere ... what value did you add to your life because of your education? If you need money ... ask for it directly ... we will give you ... do not nag us day and night for your own benefit ...,".

Like others, she found the work difficult but persisted with it:

"The classes take place at night. The learners come after working all day and are tired. Hence, they do not take much in ... their attention is easily distracted ... Moreover, they are adults ... understanding their feelings and interests and teaching them is so difficult ... it requires experience ... Imagine this road during the night ... being female ... walking alone at night ... this is my everyday life ... I feel that my life is at risk ... I walk at night alone for more than an hour ... some days I run till I reach home ... until my heart literally pounds ... sometimes I must fight with dogs ... sometimes with drunk people ... it is so terrible."

Yared's experience however was startlingly different from all the others.

"Nearly 500 adults registered. I had to divide them into two groups since it was difficult to teach them all under one roof. So, I told half of them to come to the morning session and half to come in the evening. The night shift learners collected some money and connected electric power to their centre as it had none. Then I taught both children [pre-primary] and adults in separate rooms in the morning and the remaining adults during the evening ... After a year, most of them were able to read and write simple statements. Then I decided to quit ... as I was not given the promised educational opportunity. But my students begged me to continue teaching them. They told me to remember that they are all my sisters and brothers. They said, 'If your salary is 
not adequate, we can collect money and we can support you ... please do not leave us. If we do not continue to learn, we will forget the skills you taught us.' What they said broke my heart! How can I go while they are in need of my help? I changed my mind and started my diploma in private college so as to learn at the weekends and in the evenings. But I couldn't continue with my studies as my [college] classes overlap with my learners. It was difficult for me to be selfish. So, I quit my study for the sake of helping my brothers and sisters [his students]."

Thus, Yared teaches three days a week with two classes each day, one in the morning (with children as well) and one in the evening. This means he has to balance his various commitments carefully.

Adult literacy classes mostly take place in public primary schools, though in one case at a private school, and mostly in the evenings when the schools are not being used for other purposes. One of the schools also has other evening courses, which provides a supporting environment; the others are empty and often dark. "Teaching by candlelight is not easy." Bikila teaches in a primary school which (although government supported) was established and was still being overseen by a local benefactor who felt that she "owned" the adult literacy class (she sat in on the lessons and corrected the students at times).

The basic textbook in the IFAL programme is the primer, developed and distributed by regional education bureaux in their respective regional languages based on the curriculum framework prepared at federal level. The textbook has been prepared for both facilitators and learners by involving different stakeholders such as health, agriculture, gender, etc. experts. Not all of these five ALFs had copies of the IFAL primer; some were told to find material for themselves, from school textbooks or other teaching/learning materials. Konjit said the co-ordinator told her to look for primary grade books from the education bureau. Some of the ALFs prepare substantially and use material they have collected from other sources. They say that they seek to teach the same curriculum as the primary school - languages (Amharic, Afan Oromo, English), environmental science, maths. Yared and Bikila both add some business skills from their other studies and experience. One thing they all do - at the request of the literacy learners - is teach literacy practices with mobile phones.

All of the above factors affect their confidence in teaching. Yared seems completely at ease in teaching, and the successes of his students confirm and increase his confidence. Guta and Bikila also appear confident. Konjit too retains some level of confidence, but Selam has had her confidence undermined by the daily struggles of earning enough for herself and her family and by criticism from her students and her supervisor:

"he blamed me for the absence of learners. Since he knew I sell injera, he assumes that I am not mobilising properly. He repeatedly warned me to quit my injera business and give my full attention to the job. But that is impossible for me to do." 


\section{Training and support}

For this work of teaching literacy to adults, the ALFs have had limited training. Selam and Konjit received no training from IFAL; Selam took part in a short course offered by an NGO, and Konjit received the same offer but was unable to take it up. Bikila and Guta both received a three-day orientation and a one-day course from an NGO. Yared said:

"Never! No one trained me to teach adults. I heard from my father that there was a motto during the National Literacy Campaign of the Dergue regime which said, 'All the taught have to teach' ... This implies that teaching adults does not require any special skill or training; as long as you can read and write, you can teach adults ... I think this idea still prevails; no one gave me training, even a half-day training ... Fortunately, I have some knowledge and skill of teaching that I gained during the teacher training college training. Nevertheless, an NGO gave me three days' training in how to teach pre-primary schoolchildren."

As with obtaining teaching/learning materials, it was the responsibility of the ALFs to locate and participate in training.

\section{Practising literacy}

When we explored their own literacy practices, the gender divide became even starker. The two women said that they have virtually no literacy practices in their everyday lives. Selam said that her literacy practices were nil, that even when shopping, no literacy practices were involved. She did not keep any accounts of her income-generating activities, her customers and transactions:

"Records? What for? I know my customers very well because I contact them every day; no need to write it. My husband always advises me to keep records of my daily transactions to be able to know my revenue and my expense. However, I never tried, I do not know why. Maybe because I am busy ... I wish I had that habit ... but ..."

Her general response was defensive and argumentative -

“... you want to know if I read and write. I suggest you do not waste your time ... here are my pen and paper [pointing towards the fire]. You have spent some three days with me, have you ever seen me writing or reading something? You can judge it for yourself without even asking me. I do not want to tell you a lie."

But we noticed that she checked her daughter's homework and that religious texts hung on her walls. She said she had given her prayer book to her husband: "occasionally, he reads it for me at home during holy days." She mentioned that she uses the bank for her income-generation activities. On the walls of her house, there was a large poster with the English and Amharic alphabets and a banner with the words 'HAPPY BIRTHDAY', although she insisted this was very exceptional and 
that she "would not do it next year". She kept the IFAL literacy primer and other papers at her home. She is clearly proficient in the digital literacy practices required to use a mobile phone and she teaches these. There is every evidence that she has enough literacy practices to keep her skills alive.

Konjit (a university graduate) similarly sees an absence of literacy practices in her life. When asked why she didn't post a written advertisement to promote her coffee, she replied, "Why? ... my coffee is self-promoting ... the smell draws everybody in ... It is not common to post something here ..." She does not receive a receipt for the rent she pays every month for the stall. When asked whether she has a written price list of the items she sells, she replied,

"It may surprise you, but I never think of it."

"So, how do you remember the prices?"

"Actually, I remember them ... but at times when I forget, I ... ask my neighbours because we sell the same materials ... everything requires habit ... I have no such habit ... Can you believe, I do not even know the profit of my business. I buy and sell things ... but I don't record the costs and the benefits ... this is amazing to me too. I don't look like an educated person, do I? ... I live like an illiterate person ..."

Asked about her religious literacy practices, Konjit said that she once had a prayer book that she read every morning while at university. But now she has no religious book: "I don't think I would read it if I had one now ... when do I [have time to] read a prayer book? God will understand me."

Although she didn't consider it a literacy practice, she uses a bank account to save money. She also has and uses a mobile phone, but when asked by one of her customers why she didn't reply to his text messages and why she doesn't use Facebook, she replied,

"You will find more than 40 unread messages on my mobile phone ... as you can see, I am a very busy person ... I have no time to read and reply ... sorry! ... anyway, I cannot eat or wear Facebook! I must work like a bee now ... I have no time for that ..."

She also, on occasion, collects money for the local credit and savings group she belongs to, which requires some practice of literacy. She also submits written monthly or bimonthly learner attendance reports to her supervisor. Her concept of "literacy" does not seem to embrace these activities.

The others' lives are replete with literacy practices. Yared runs a typing agency and a library, with forms for people to fill in; he reads widely in his spare time and writes:

"I write Amharic poems. I have more than 32 pages of poems. Early in the morning, when a thought comes to my mind, I write a poem, usually a love poem. I also write various aphorisms. Some of my friends have posted these inside their cars. For instance, one of my aphorisms is Kemeqinat mesrate [Instead of envying, it is better to work]."

When asked about his reading, 
"Sure! I love fiction, especially Haddis Alemayehu's Fiqir Eskemeqabir [a classic Amharic novel, whose title means 'Love unto the grave']. I read it first after borrowing it from friends. Now, the woreda awarded me this book for my performance in teaching adults. In addition to fiction, I love reading newspapers and magazines. When I go to ... town, I usually go the centre where I can find various magazines and newspapers ... I can say I am addicted to going there to read ... Surprisingly, I have learned more from my own reading than I did at school over the last 13 years. Reading helped me to have a broader perspective ... It also helps to make my teaching authentic and to give real examples to my students."

Guta says that he reads many books - history, short stories written in Afan Oromo and subjects related to accounting, including course handouts. He listed eight books which he had bought, and discussed one novel in detail. Among his books were religious texts and an English dictionary. Bikila, however, said that he came to reading late:

"My background in primary and lower secondary school was limited to student textbooks in the Afan Oromo language. My local experience, particularly in the rural environment, did not help me to get access to a reading habit because there is no library, no books and no newsagents."

Even though primary and secondary school textbooks are sold at the roadside in some villages, Bikila said,

"I could not afford these ... When I came to the city, I could not much improve my condition because I immediately started day labouring to support myself. After I joined [the College], I started reading newsletters, distance learning material on civics and psychology from the Teachers College, and cultural and religious reading. I read primary school textbooks, particularly in Afan Oromo, on civics, and social studies materials which have some similarities with the textbook [the IFAL literacy primer] ... I used to read on the Internet but because of the poor quality of my mobile phone, I can no longer access it."

\section{Aspirations}

What then of their personal aspirations and attitudes towards the IFAL programme on which they teach? Selam saw her work as an adult literacy facilitator less as a career step than as a response to the need for income. As she said, the low pay and the poor relationships with her supervisor were such that she felt she may soon move on:

"I am almost losing my patience. I cannot withstand the coordinator's blame and other challenges. I will try for some time but [if it doesn't improve] I will leave my job. What else can I do?"

Konjit, as a graduate, saw the experience as useful in getting another job: 
“The work doesn't satisfy you ... I am working as a facilitator until I get a better job ... it doesn't match my educational level ... the salary is very low ... Until I get a better job, I will work ... Since many job applications require teaching experience, this experience will help me to get a [better] job in the future."

Yared, referring to facilitators who left, said:

"I am the only one who stayed. I will also quit as soon as I finish my diploma. In fact, I didn't want to wait that long, but my students wanted me to stay ... I regret all the time my loss of education. I have a big dream; I want to become a professor. I am also planning to learn the English language this summer. Language is very important at this time; most of the materials I found on the Internet are written in the English language."

Bikila similarly sees the work as a useful step in a planned career:

"Like any young adult living in this country, I have my own dream. The current job is a stepping stone. If I get another job with better payment, I will change because the current payment is not enough ... I am here for the time being; I don't want to stay in this profession as long as there is no salary improvement, and I would like to improve myself if other opportunities come along."

Guta, on the other hand, said that he will continue working as an ALF for the next three years while he studies.

"I have no additional family burden but I have a girlfriend. She completed her college education in nursing this year but is not yet employed. I am going to be engaged, maybe one year after completing my study in accounting."

\section{Discussion}

Looking at these five individual cases, a number of general considerations strike us.

\section{Diversity of ALFs}

The clearest lesson from this pilot study is the diversity among the facilitators. They differ in sex, in age, in family background and in their past experiences. They differ in educational background, from Grade 10 completers to university graduates - and clearly the extent of their foundational education affects not only their abilities to teach literacy but also their attitudes towards education for themselves and for others, and the ways in which they teach. They also differ in levels of confidence, that most important factor in teaching. All of the facilitators we studied have a strong dedication to improving their lives and are hard workers; all are very committed to schooling, have struggled hard to achieve it for themselves and promote schooling among their adult literacy learners, including using school curricula and teaching/learning methodologies rather than adult participatory 
practices. This may not, of course, be true of other facilitators; once again there will be a large diversity of experiences, attitudes and values. This suggests that a onesize-fits-all approach to their training and their supervision would be inappropriate.

\section{Experiences of education}

Their educational experiences were clearly very important to these five ALFs - they shaped their own understanding of education, so that they saw their work as adult literacy facilitators in terms of formal schooling. But they recognised that teaching adults is a difficult task. One facilitator felt that she was not able to fulfil the task and soon after our study moved to a different teaching role, more suited to her personality and commitments. Another facilitator built up extensive experience which could be used to help train others. The experience and capabilities of some facilitators can be used as a resource for their development.

\section{Multiple motivations}

Our case studies revealed mixed motivations for teaching literacy. Earning a regular income was one; a hope that it will lead to more rewarding forms of teaching was clearly another; and for some a commitment to helping non-literate adults was a motivating factor. Rarely is one motive alone enough to maintain ALFs in their accepted task.

\section{Literacy teaching as a secondary concern}

For these facilitators, teaching adults is a secondary concern; it can never be their first priority, their full-time occupation. Even if they are not engaged in other forms of education (studying for their own careers) or earning a living, they have family commitments which come before their adult literacy teaching. Each has multiple roles and identities. But these other concerns, as our case studies suggest, are not necessarily a hindrance to their work. Some of these interests contribute to the experience which the facilitators bring to the adult classes. The three facilitators who are studying bring information from their studies, while those engaged in other forms of work contribute from these experiences skills and knowledge which the adult literacy learners wish to learn. ALFs bring their whole lives to their work; they cannot compartmentalise, and the interests of the learners coincide, in many cases, with those of the facilitators. ALFs teach much more than literacy in their classes; as role models, they share their ways of life, even if they are not conscious of doing so.

\section{Literacy practices}

This role is most clearly evident in the literacy practices of facilitators. Those who had many everyday literacy practices helped their literacy learners to engage more fully, while those who used fewer found it hard to engage the literacy learners. All five ALFs applied mobile phone literacy practices in their lessons, something in which the learners had expressed keen interest - but while some found it possible to 
build on this interest, others remained at a very basic level. Our studies suggest that a development programme for facilitators that focused on enhancing their own literacy practices could contribute to their effectiveness.

\section{Gender}

The fact that Selam and Konjit used their mobile phones in very limited ways while the three male facilitators used theirs to learn various things besides communication, reflects a strong gender dimension to this study. The female facilitators had to struggle against many forces to attend and complete their schooling. Both were criticised by their supervisors, and both felt that they were undermined and disregarded by the community members during mobilisation - whereas the males did not; Yared said he never faced this problem as he has strong support from the kebele leaders. The women also had more domestic responsibilities than the male facilitators. The female facilitators struggled, with some measure of success, against cultural assumptions regarding their roles and behaviour; the men had far greater freedom of choice. But we also need to note that the women did not give up completely; they continued to struggle and earn a livelihood for themselves and their families, and they resisted the dominant culture. Gender relations will, of course, vary from context to context. We noted in our research that, for example, while it was acceptable for a male researcher to interview a woman, it was much harder and required a great deal of tact as well as time for a woman researcher to interview a male ALF. Such examples reflect the particular culture of these two Ethiopian contexts but they also have wider applications.

\section{Professional development for facilitators}

We believe that our case studies reveal an urgent need for diverse programmes of professional development for these and other ALFs who comprise a large and potentially very influential group of development workers. None of these facilitators received more than very limited training or development, and three of them were expected to find their own training. If they are to contribute to the effectiveness of IFAL, they need not only pre-service training but ongoing support from experienced staff. This should be conducted in a participatory way to take advantage of the diversity of experience and the different qualities which the facilitators bring with them. Similar research in South India (Rogers et al. 2003 [1989]) proposed the formation of groups and networks of facilitators who through shared learning were able to support each other. In Uganda (Rogers 2008), relatively isolated facilitators developed informal support networks without any urging from their supervisors. No doubt, further research would find these in other localities. But this does not excuse the managing staff from their obligation to provide for the training and continuing development of the facilitators they employ and from whom they require so much. Men and women who give their time and energies to teaching literacy to adults for little reward deserve better support throughout the whole programme. 


\section{Conclusion}

We wish to stress that we do not regard these five ALFs as representative, even of ALFs in the Ethiopian IFAL programme. Our aim is to see if understanding their background will help their supervisors and all concerned with the recruitment and development of ALFs to help them work more effectively.

We believe that similar surveys in other contexts will reveal important issues and questions about ALFs and how they may be supported in their difficult work. Simply to assume that we already know and that with the existing levels of support they can do a good job, even more to think that any failings of the literacy learning programmes come from the weaknesses of the ALFs - these are not acceptable attitudes on the part of the managers of ALLPs. Until we know more about the ALFs, what they bring to their teaching and which challenges they face, we will never help them to achieve greater effectiveness.

This pilot study, we submit, suggests that detailed studies (using ethnographic or other approaches) can lead to a more supportive programme for the enhancement of their work and thus to more effective adult literacy learning programmes. We need more studies if adult literacy facilitators are to become more successful.

Acknowledgements We are grateful to the staff and students of Bahir Dar and Arsi Universities, who commented on early drafts of the case studies. Our thanks also go to Professor Anna Robinson-Pant, who commented on an early draft.

Funding information The authors acknowledge assistance from the Adult Education and Community Development Department, Education and Behavioral Sciences College, Bahir Dar University, Ethiopia for the initial survey.

Open Access This article is distributed under the terms of the Creative Commons Attribution 4.0 International License (http://creativecommons.org/licenses/by/4.0/), which permits unrestricted use, distribution, and reproduction in any medium, provided you give appropriate credit to the original author(s) and the source, provide a link to the Creative Commons license, and indicate if changes were made.

\section{References}

Bartlett, L. (2010). The word and the world: The cultural politics of literacy in Brazil. Cresskill, NJ: Hampton Press.

Barton, D. (2012). Ethnographic approaches to literacy research. In Chapelle, C. A. (Ed.), Encyclopedia of applied linguistics [online]. Chichester: Wiley-Blackwell. doi:10.1002/9781405198431. wbeal0398.

Barton, D. (2013). The threat of a good example: How ethnographic case studies challenge dominant discourses. In J. Kalman \& B. Street (Eds.), Literacy and numeracy in Latin America: Local perspectives and beyond (pp. 214-219). London: Routledge.

Diarra, M. C. (2011). Formation des formateurs: place dans une education de qualite des adultes. International Review of Education, 57(1-2), 473-481.

Doyle, L., Egetenmeyer, R., Singai, C., \& Devi, U. (2016). Professionalisation as development and as regulation: Adult education in Germany, the UK and India. International Review of Education, 62(3), 317-341.

Ellen, R. F. (1984). Ethnographic research: A guide to general conduct. San Diego: Academic Press. 
Gebre, A. H., Rogers, A., \& Street, B. (2009). Everyday literacy practices in Africa; Ethnographic studies of literacy an numeracy in Ethiopia. Kampala: Fountains Press. Retrieved 12 September 2017 from http://www.balid.org.uk/wp-content/uploads/2012/12/Ethiopia-whole-book-knj.pdf.

Geertz, C. (1973). The interpretation of cultures. New York: Basic Books.

Ghose, M. (Ed.). (2007). Exploring the everyday: Ethnographic studies of literacy. New Delhi/Mumbai: Nirantar/ASPBAE. Parts 1-3, retrieved 9 October 2017 from http://www.nirantar.net/uploads/files/ Part1.pdf, http://www.nirantar.net/uploads/files/part2.pdf, http:/www.nirantar.net/uploads/files/ part3.pdf.

Hammersley, M. (1992). So, what are case studies? and The logic of theory-testing in case study research. In M. Hammersley (Ed.), What's wrong with ethnography? Methodological explorations (pp. 174-200). London: Routledge.

Hanemann, U. (2015). Lifelong literacy: Some trends and issues in conceptualising and operationalising literacy from a lifelong learning perspective. International Review of Education, 61(3), 295-326.

Lytle, S., Belyer, A., \& Reumann, R. (1993). Initiating practitioner inquiry: Adult literacy teachers, tutors and administrators research their practice. Philadelphia, PA: National Center on Adult Literacy (NCAL), University of Pennsylvania.

Maruatona, T. (2012). An argument for the professionalization of literacy facilitators for Quality Education in Southern Africa. PULA: Botswana Journal of African Studies, 26(2), 187-203. Retrieved 12 September 2017 from http://journals.ub.bw/index.php/pula/article/view/164/37.

Mayombe, C., \& Lombard, A. (2016). The importance of material resources and qualified trainers in adult non-formal education and training centres in South Africa. International Review of Education, 62(2), 187-204.

McCaffery, J. (2004). Closing the gap: Issues of gender-integrated training of adult literacy facilitatorspossibilities, progress and resistance. In A. Robinson-Pant (Ed.), Women, literacy and development: Alternative perspectives (pp. 159-177). London: Routledge.

MoE (Ministry of Education). (2010). Education Sector Development Program IV (2010/2011-2014/ 2015). Addis Ababa: Ministry of Education.

Nabi, R., Rogers, A., \& Street, B. (2009). Hidden literacies: Ethnographic studies of literacy and numeracy practices in Pakistan. Bury St Edmunds: Uppingham Press. Retrieved 12 September 2017 from http://www.balid.org.uk/wp-content/uploads/2012/12/HiddenLiteracies_all_02.pdf.

Negassa, T., Rogers, A., \& Zalalam, T. (2017). How do adults learn to read? A communities of practice approach. Prospects. https://doi.org/10.1007/s11125-017-9405-x.

Oluoch, A., Ayodo, T. M. O., Simatwa, E., \& Othuon, L. A. (2014). Evaluation of facilitators' skills in assessing the achievement of in literacy programme in Vihiga (Kenya). Greener Journal of Education and Training Studies, 2(3), 58-63.

Openjuru, G. (2002). Comparative study of FAL and REFLECT adult literacy facilitator training process in Uganda. Unpublished PhD Thesis, University of Kwa-Zulu Natal, South Africa.

Openjuru, G., Baker, D., Rogers, A., \& Street, B. (Eds.). (2016). Exploring literacy and numeracy practices: Ethnographic case studies from Uganda. Bury St Edmunds: Uppingham Press.

Paluch, M. (2013). "Leaders", “Carers", "Developers" and "Tutors": Identities of adult literacy facilitators in Guatemala. M.A. Dissertation, University of Sussex, Brighton, UK. Retrieved 12 September 2017 from http://www.academia.edu/20395022/_Leaders_Carers_Developers_and_ Tutors_-_identities_of_adult_literacy_facilitators_in_Guatemala.

Prinsloo, M., \& Breier, M. (1997). Social uses of literacy. Amsterdam: Benjamins.

Robinson-Pant, A. (2001) Why eat green cucumber at the time of dying? Exploring the link between women's literacy and development: A Nepal perspective. Hamburg: UNESCO Institute of Education (UIE). Retrieved 12 September 2017 from http://unesdoc.unesco.org/images/0012/001236/123606e. pdf.

Robinson-Pant, A. (Ed.). (2004). Women, literacy and development: Alternative perspectives. London: Routledge.

Rogers, A. (2008). Report of consultancy on functional adult literacy programmes in Kalangala and Buvuma islands provided by the government of Uganda, Ministry of gender, labour and social development, and supported by ICEIDA. Reykjavik: Icelandic International Development Agency/ Ministry for Foreign Affairs. Retrieved 8 April 2012 from www.iceida.is/media/pdf/UGANDA_ REPORT.PDF.

Rogers, A., with Elias, M. J., Ranjanidas, \& Ramaswamy, P. (2003 [1989]). Partners in Literacy: A pilot attitudinal survey of rural literacy instructors in Tamil Nadu, India (2nd ed.). Bury St Edmunds: 
Uppingham Press. University of Madras, Education for Development. Retrieved 12 September 2017 from http://www.totald.org.uk/images/downloads/pilcomplete.pdf.

Street, B. V. (Ed.). (1993). Cross-cultural approaches to literacy. Cambridge: Cambridge University Press.

Torres, R. M. (2004). Lifelong learning in the South: Critical issues and opportunities for adult education (Vol. 11). Sida studies series. Stockholm: Swedish International Development Cooperation Agency (SIDA). Retrieved 12 September 2017 from http:/www.sida.se/contentassets/ d60c67d64bf947b1b147419f7751a466/lifelong-learning-in-the-south-critical-issues-andopportunities-for-adult-education_1614.pdf.

Torres, R. M. (2009). From literacy to lifelong learning: Trends, issues and challenges in youth and adult education in Latin America and the Caribbean. Hamburg: UNESCO Institute for Lifelong Learning (UIL).

UIL (UNESCO Institute for Lifelong Learning). (2009). Global report on adult learning and education. Hamburg: UIL. Retrieved 12 September 2017 from http://uil.unesco.org/fileadmin/keydocuments/ AdultEducation/en/GRALE_en.pdf.

UIL (2012). Quality matters: Improving the status of literacy teaching personnel. UIL Policy Brief 1. Hamburg: UIL. Retrieved 12 September 2017 from http://unesdoc.unesco.org/images/0022/002224/ 222448e.pdf.

UNDP (United Nations Development Programme). (2015). Work for human development. Human Development Report 2015. Retrieved 12 September 2017 from http://hdr.undp.org/sites/default/ files/2015_human_development_report.pdf.

UNESCO (United Nations Educational, Scientific and Cultural Organization). (2006). Literacy for life. Global Monitoring Report 2006. Paris: UNESCO. Retrieved 12 September 2017 from http:// unesdoc.unesco.org/images/0014/001416/141639e.pdf.

Wahlgren, B. (2016). Adult educators' core competences. International Review of Education, 62(3), 343-353.

Weber, R.-M. (1999). Adult education and literacy. In D. A. Wagner, R. L. Venezky, \& B. V. Street (Eds.), Literacy: An international handbook (pp. 173-178). Boulder, CO: Westview Press.

Werqneh, T. (2012). The adult education practice in Ethiopia. Addis Ababa: Alpha Printers.

Youngman, F., \& Singh, M. (2005). Strengthening the training of adult educators. Report on the Workshop Held at the CONFINTEA Mid-term Review Conference, Bangkok, Thailand, September 2003. Hamburg: UNESCO Institute for Education (UIE). Retrieved 12 September 2017 from http:// www.unesco.org/education/uie/pdf/trainingofaded.pdf.

Zalalam, T., Menkir, A., Oljira, T., \& Tegegn, E. (2015). A survey on adult literacy facilitators in Amhara Region. Unpublished report. Bahir Dar: Bahir Dar University Adult Education and Community Development Department.

\section{The authors}

Turuwark Zalalam Warkineh studied Adult Education and Lifelong Learning; she is working as a lecturer and head of the Department of Adult Education and Community Development, Bahir Dar University, Ethiopia. She was a country-study team member of the UNESCO-International Fund for Agricultural Development (IFAD) international research project, led by Professor Anna Robinson-Pant. She currently coordinates UNESCO Chair (Adult Literacy and Learning for Social Transformation) activities in Ethiopia, chaired by Professor Robinson-Pant. Her research interests include adult literacy, informal learning, workplace learning, lifelong learning and crafts learning.

Alan Rogers is Visiting Professor at the University of East Anglia, UK, where (with Professor Anna Robinson-Pant, UNESCO Chair for Adult Literacy and Social Transformation) he teaches on the MA in Adult Literacy and Development. He was formerly Executive Director of Education for Development; he is the author (with Professor Brian Street) of Adult Literacy and Development: stories from the field (Leicester: NIACE 2010) and other books and articles on adult learning and literacy.

Tolera Negassa Danki studied Adult Education and Lifelong Learning. He served at different universities in Ethiopia; currently, he is working as lecturer and Dean of the College of Education and Behavioral Science, Arsi University, Ethiopia. 